\title{
Effect of GLP-1 on D-glucose transport, lipolysis and lipogenesis in adipocytes of obese subjects
}

\author{
VERÓNICA SANCHO ${ }^{1}$, MARÍA V. TRIGO ${ }^{1}$, ANTONIO MARTÍN-DUCE ${ }^{2}$, \\ NIEVES GONZÁLEZ ${ }^{1}$, ALICIA ACITORES ${ }^{1}$, LUIS ARNÉS ${ }^{1}$, ISABEL VALVERDE ${ }^{1}$, \\ WILLY J. MALAISSE ${ }^{3}$ and MARÍA L. VILLANUEVA-PEÑACARRILLO ${ }^{1}$
}

\begin{abstract}
${ }^{1}$ Department of Metabolism, Nutrition and Hormones, Fundación Jiménez Díaz, Avda. Reyes Católicos 2, 28040 Madrid; ${ }^{2}$ Department of Surgery, Hospital Príncipe de Asturias, Universidad de Alcalá de Henares, Ctra. Meco (M-121) s/n, Alcalá de Henares, 28805 Madrid, Spain; ${ }^{3}$ Laboratory of Experimental Hormonology, Faculté de Médecine, Université Libre de Bruxelles, Route Lennik 808, B-1070 Brussels, Belgium
\end{abstract}

Received October 12, 2005; Accepted December 5, 2005

\begin{abstract}
GLP-1 has anorectic properties and regulates fuel homeostasis through both its insulinotropic and insulinotrophic actions and effects in extrapancreatic tissue. This study is aimed at characterizing the response to GLP-1 of adipocytes from obese patients, in terms of D-glucose transport and lipid metabolism, in comparison with data from normal subjects. Adipocytes were obtained by enzymatic digestion from the abdominal fat tissue of 25 morbidly obese patients and 8 normal subjects undergoing bariatric or inguinal hernia surgery, respectively. Basal GLUT4 expression, D-glucose transport, glycerol release and lipogenesis were measured in cells treated, when required, with $10^{-12}-10^{-9} \mathrm{M}$ GLP-1, insulin, glucagon and the GLP-1 structurally related peptides, exendin- 4 and exendin-9. In obese patients, versus normal subjects, a trend towards lower values was found in GLUT4 protein or mRNA, although the differences were not statistically significant; insulin-stimulated glucose uptake was higher and cells did not respond to GLP-1, while both exendins $\left(10^{-10}\right.$ and $\left.10^{-9} \mathrm{M}\right)$ exerted an inhibitory action; basal lipolysis was higher and so was the effect of GLP-1 and glucagon, whereas insulin abolished the lipolytic action of all peptides; both basal lipogenesis and the response to insulin were higher while GLP-1 and exendin- 4 were ineffective. These results document the analogies and dissimilarities between the response to GLP-1, exendin-4 and exendin-9, as well as to insulin and glucagon, relative to glucose transport and lipid metabolism of fat tissue from obese patients versus normal subjects, the reduced lipogenic effect and enhanced lipolytic action of GLP-1 being, perhaps, adequate for its therapeutic use in obesity.
\end{abstract}

Correspondence to: Dr María L. Villanueva-Peñacarrillo, Department of Metabolism, Nutrition and Hormones, Fundación Jiménez Díaz, Avda. Reyes Católicos 2, 28040 Madrid, Spain E-mail: mlvillanueva@fjd.es

Key words: GLP-1, glucose transport, GLUT4, lipid metabolism, obesity

\section{Introduction}

GLP-1, apart from its proven insulinomimetic properties per se $(1,2)$, antidiabetic character (3), and stimulatory action upon both the expression of glucotransporter genes (4) and the transport and metabolism of glucose in extrapancreatic tissue $(2,5,6)$, exerts a dual effect in normal rat and human adipocytes (6-9), stimulating not only the mechanism of lipogenesis but also that of lipolysis. These effects of GLP-1 in fat, like those in liver $(10)$ and muscle $(11,12)$, are exerted through a GLP-1specific receptor (13-15), structurally or functionally distinct $(10,11,16)$ from that in the pancreas $(17)$. In these three extrapancreatic tissues, GLP-1, like insulin, increases the activity of several kinases (PI3K, PKB, p44/42 MAPKs, p70s6k), some of them being determinant for the peptide action $(6,18,19)$.

GLP-1 also inhibits gastric emptying and controls food intake by enhancing satiety (3). Morever, changes in GLP-1 secretion were reported in morbidly obese patients (20-22).

Exendin(1-39)amide (Ex-4), a non-mammalian peptide, shares $53 \%$ of its amino-acid sequence with GLP-1; it is also insulinotropic (23) and exerts GLP-1-like effects upon parameters related with the glucose metabolism in rat liver and skeletal muscle (24). Its truncated form, exendin(9-39)amide (Ex-9), has proven to be an antagonist of the GLP-1 receptor in various cell systems (25) and also of its effects in rat pancreas (26), liver cells and muscle tissue (24); however, in human myocytes, both exendins increase glucose transport and metabolism $(12,27)$ and have proven to be an agonist of the GLP-1 receptor in adipocyte (28) and myocyte (16) cell lines.

In recent studies, we have compared the effect of GLP-1 to that of other hormones such as insulin and glucagon on lipolysis and lipogenesis in adipocytes isolated from normal subjects (9). The major aim of the present study, already reported in part in abstract form (Arnés, et al, Diabetologia 47: abs, 55, 2004), was to determine possible differences in the expression of the glucotransporter GLUT4, and in the effect of GLP-1 upon glucose transport and lipid metabolism in adipocytes from obese patients, as compared to normal subjects. 


\section{Materials and methods}

Reagents. Human GLP-1(7-36)amide (GLP-1, Bachem AG, Bubendorf, Switzerland); pork insulin (Novo Biolabs, Bagsvaerd, Denmark); pork glucagon (Lilly Co., Indianapolis, IN, USA); exendin(1-39)amide (Ex-4) and exendin(9-39)amide (Ex-9) as gifts from Dr John Eng (VAMC, NY, USA); bovine serum albumin (BSA), glycerol and cytochalasin B (Sigma Chemical Co., St. Louis, MO, USA); aprotinin (Trasylol ${ }^{\circledR}$, Bayer Leverkusen, Germany); $\left[2-{ }^{14} \mathrm{C}\right]$ sodium acetate (Amersham Pharmacia Biotech, Buckinghamshire, UK); 2-deoxy-D[1,2- $\left.{ }^{3} \mathrm{H}(\mathrm{N})\right]$ glucose (2-DOG, Moravek Biochemicals, Brea, CA, USA); dioctyl phthalate (Acros Organics, NJ, USA); Ultima Gold scintillation liquid (Packard, Gröninger, The Netherlands); adenosine triphosphate (ATP) and nicotinamide adenine dinucleotide (NAD) (Boehringer Mannheim, S.A., Barcelona, Spain); and C-terminal GLUT4 rabbit polyclonal antibody (Wak-Chemie Medical GmbH, Bad Soden, Germany) were obtained from the cited sources. All other commonly used chemicals were from Sigma or Merck (Merck Pharma Quimica, S.A., Barcelona, Spain).

Biological material. Residual samples of subcutaneous abdominal fat tissue were collected, after informed consent was obtained, from 25 morbidly obese patients $(22 \mathrm{~F} / 3 \mathrm{M})$ undergoing bariatric surgery. They were $42.2 \pm 2.1$ years old, with a mean body mass index (BMI) of $50.3 \pm 1.3 \mathrm{~kg} / \mathrm{m}^{2}$. Their fasting plasma D-glucose and HDL concentration averaged $5.69 \pm 0.25 \mathrm{mM}(\mathrm{n}=23)$ and $41.0 \pm 2.7 \mathrm{mg} / \mathrm{dl}(\mathrm{n}=19)$, respectively. The patients examined for each variable under consideration were not selected in any specific manner.

Most of the data collected in normal control subjects, and used for the purpose of comparison with some of the measurements made in the present study, were already reported elsewhere (9). For glucotransporter measurements, tissue samples from a group of normal subjects $(6 \mathrm{~F} / 2 \mathrm{M}$; $39 \pm 3$ years; BMI: $24.9 \pm 0.5 \mathrm{~kg} / \mathrm{m}^{2}$; fasting plasma D-glucose: $5.02 \pm 0.13 \mathrm{mM}$ ) were collected during inguinal hernia surgery. In all cases, the comparison between control subjects and obese patients was restricted to results obtained under similar experimental conditions. The tissue samples were used either to extract plasma membranes and/or RNA, as previously described in detail (4), or to isolate adipocytes.

The study was approved by the Ethics Committee of the Fundación Jiménez Díaz, Madrid, in accordance with the guidelines proposed in The Declaration of Helsinki.

Cells. Adipocytes were isolated at $37^{\circ} \mathrm{C}$, by enzymatic digestion with collagenase $\mathrm{P}$, from subcutaneous abdominal fat tissue, according to Rodbell (29). Then, cells were initially resuspended in KRB supplemented with 10.9 mM HEPES, $500 \mathrm{KIU} / \mathrm{ml}$ Trasylol, 3\% BSA and without or with D-glucose, $\mathrm{pH} 7.4$, at a density of $10^{6}$ cells $/ \mathrm{ml}$.

GLUT4, protein and $m R N A$. GLUT4 protein was measured by Western blotting, in $25-50 \mu \mathrm{g}$ membrane protein samples using a C-terminal GLUT4 rabbit polyclonal antibody, as previously described (4). mRNA was determined by Northern blotting, in RNA extract from 100-200 mg tissue, using the protocol and reagents described (4).
Glucose transport. Cells $\left(10^{5}\right)$ were incubated for $15 \mathrm{~min}$ at $37^{\circ} \mathrm{C}$ in $400 \mu \mathrm{KRB}, 10.9 \mathrm{mM}$ HEPES, $500 \mathrm{KIU} / \mathrm{ml}$ Trasylol and $2 \%$ BSA, pH 7.4, without (basal) or with GLP-1, Ex-4, Ex-9, glucagon or insulin. This was followed by 3-min incubation in the additional presence of $0.2 \mu \mathrm{Ci}(6.5 \mathrm{pmol})$ of 2-deoxy-D-[1,2- $\left.{ }^{3} \mathrm{H}(\mathrm{N})\right]$ glucose (final concentration, $16.3 \mathrm{nM}$ 2-DOG). Adipocytes, after being separated at 10,900 $\mathrm{g}$ in $100 \mu \mathrm{l}$ dioctyl phthalate, were added to $3 \mathrm{ml}$ scintillation liquid for $\beta$-counting. The total glucose content was corrected by the unspecific glucose uptake value obtained in cell samples from each experiment treated in parallel with $0.175 \mathrm{mM}$ cytochalasin B (8).

Lipid metabolism. Lipolysis was determined as glycerol release, following Wieland's enzymatic procedure (30), with some modifications (31). In brief, isolated adipocytes $\left(10^{5}\right.$ cells) were incubated for $60 \mathrm{~min}$ at $37^{\circ} \mathrm{C}$ in $300 \mu \mathrm{KRB}$ supplemented with $10.9 \mathrm{mM}$ HEPES, $500 \mathrm{KIU} / \mathrm{ml}$ Trasylol, $3.3 \mathrm{mM}$ Dglucose and $3 \% \mathrm{BSA}$, either in the absence (basal) or presence of GLP-1, Ex-4, glucagon or insulin, alone or in combination; thereafter, $0.45 \mathrm{M} \mathrm{HClO}_{4}$ was added to the media, the mixture was maintained for $10 \mathrm{~min}$ at $4{ }^{\circ} \mathrm{C}$ and then centrifuged at $2,000 \mathrm{x}$ g. The supernatant was neutralized with $20 \% \mathrm{KCO}_{3} \mathrm{H}$, separated at 3,000 g, and its glycerol content was spectrophotometrically measured as NADH produced in the presence of ATP, NAD and the appropriate enzymes, from the absorption at $340 \mathrm{~nm}$; known amounts of glycerol were used as standard of reference. Lipogenesis was studied as the incorporation of $\left[2-{ }^{14} \mathrm{C}\right] \mathrm{Na}$ acetate, as precursor, into lipids. Adipocytes $\left(10^{5}\right.$ cells) were incubated at $37^{\circ} \mathrm{C}$ for $15 \mathrm{~min}$ in $400 \mu \mathrm{l}$ of the same medium as described above, either without (basal) or with GLP-1, Ex-4, Ex-9 or insulin. This was followed by a 60 -min incubation at $37^{\circ} \mathrm{C}$ in the additional presence of $0.4 \mathrm{mM}$ $\left[2-{ }^{14} \mathrm{C}\right] \mathrm{Na}$ acetate $(0.156 \mu \mathrm{Ci} / \mu \mathrm{mol})$. Adipocytes, after being separated at 10,900 $\mathrm{g}$ in $100 \mu 1$ dioctyl phthalate, were added to $3 \mathrm{ml}$ scintillation liquid for $\beta$-counting and the data were corrected for background values, as found in vials containing all reagents but no cells and subjected in parallel to the same procedure.

Statistical study. All results, including those already mentioned, are presented as mean values $( \pm$ SEM) together with the number of individual determinations (n) or degree of freedom (d.f.). The statistical significance $(\mathrm{p}<0.05)$ of the increments was assessed by one-way analysis of variance, followed by the least significant differences (LSD) test for post-hoc multiple comparisons using the statistical package for the social science (SPSS) software or, when appropriated, by the Student's t-test.

\section{Results}

GLUT4 and D-glucose transport. In the adipocytes of eight obese patients, the GLUT4/ß-actin mRNA ratio averaged $0.395 \pm 0.052$, slightly lower but not significantly different ( $\mathrm{p}>0.5)$ from that found in normal subjects $(0.460 \pm 0.086$; $\mathrm{n}=4$ ). Likewise, the GLUT4 protein content (Fig. 1) represented, in adipocytes of obese patients, $81.9 \pm 14.1 \%$ $(\mathrm{n}=11)$ of the mean corresponding value found in normal subjects $(100.0 \pm 15.9 \% ; n=6)$. 


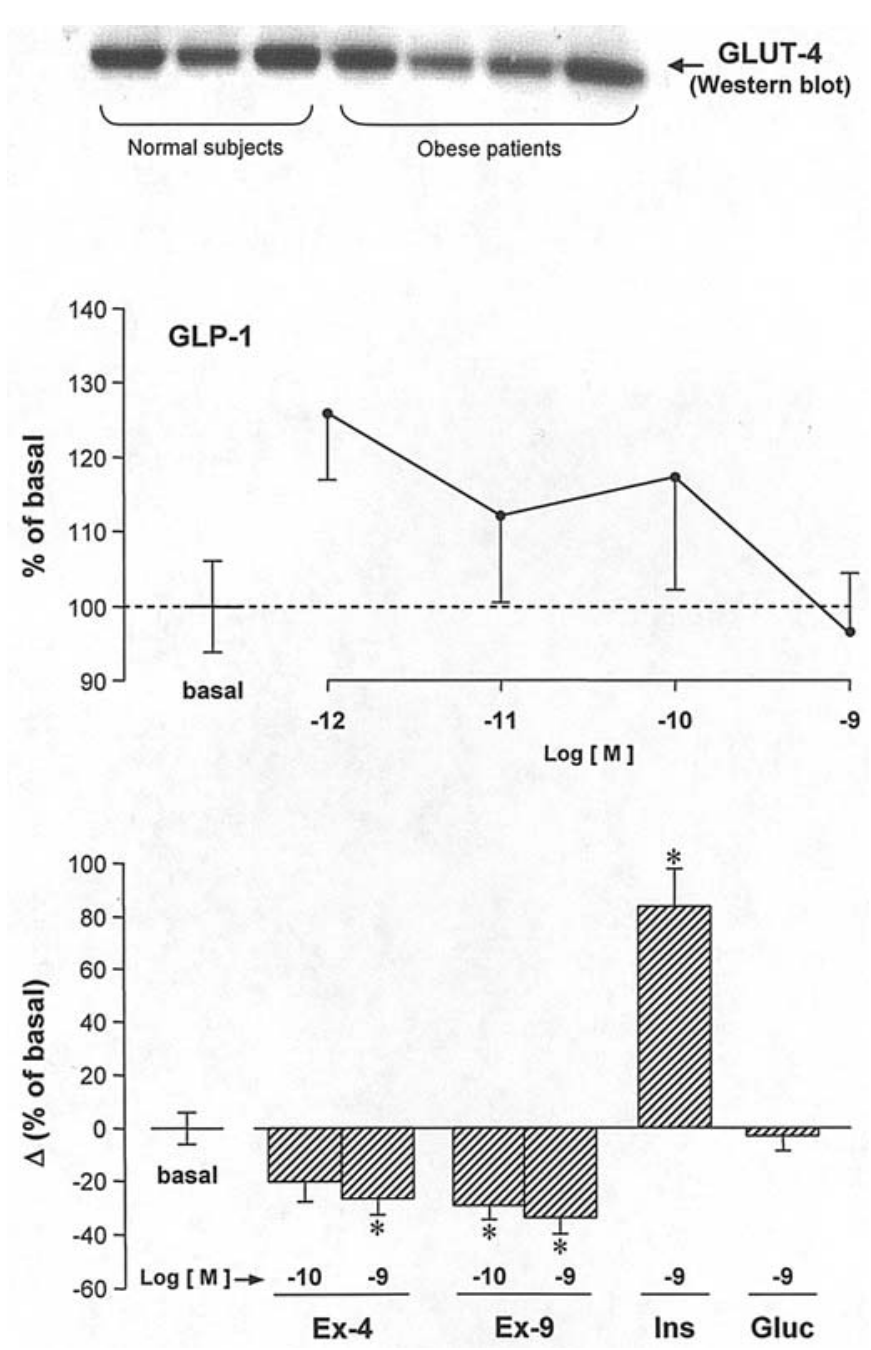

Figure 1. Basal GLUT4 in adipocytes from morbidly obese patients and normal subjects (representative immunoblot) (upper panel), and the effect of GLP-1 (middle panel) and Ex-4, Ex-9, insulin (Ins) and glucagon (Gluc) (lower panel) upon 2-deoxy-D-glucose uptake by isolated adipocytes from five morbidly obese patients. Data (mean \pm SEM) are expressed in percent, total or increment, relative to paired basal value. ${ }^{*} \mathrm{p}<0.04$.

As shown in Fig. 1, in adipocytes of the obese group, the uptake of 2-deoxy-D-glucose, expressed relative to paired mean basal value $\left(14.95 \pm 1.83 \mathrm{fmol} / 10^{5}\right.$ cells, $\mathrm{n}=5$ subjects $)$, was increased $(\mathrm{p}<0.001)$ to $183.5 \pm 14.5 \%$ by $10^{-9} \mathrm{M}$ insulin but not affected $(\mathrm{p}>0.80)$ by glucagon (also $10^{-9} \mathrm{M}$ ). GLP-1 did not significantly modify 2-deoxy-D-glucose uptake at any concentration tested. Moreover, the GLP-1 structurally related peptide, Ex-4 (10-10-10-9 M), inhibited 2-deoxy-Dglucose uptake, the decrease reaching statistical significance at $10^{-9} \mathrm{M}(\mathrm{p}<0.05)$; such was also the case in response to Ex-9 $(\mathrm{p}<0.05)$, at both concentrations tested. At equal concentrations $\left(10^{-10}\right.$ and $\left.10^{-9} \mathrm{M}\right)$, the uptake of 2-deoxyD-glucose in the presence of Ex-4 and Ex-9 averaged, respectively, $72.1 \pm 4.4 \%(\mathrm{n}=10 ; \mathrm{p}<0.001)$ and $69.6 \pm 3.8 \%$ $(\mathrm{n}=10 ; \mathrm{p}<0.001)$ of the mean corresponding values found in the presence of GLP-1 $(100.0 \pm 8.7 \% ; n=10)$. The inhibitory action of Ex-4 and Ex-9 failed, however, to differ significantly ( $>0.2)$ from one another, the results obtained with the latter agent averaging $96.7 \pm 5.3 \%(\mathrm{n}=10)$ of the mean corresponding values obtained with $\mathrm{Ex}-4(100.0 \pm 6.1 \%$; $=10)$.
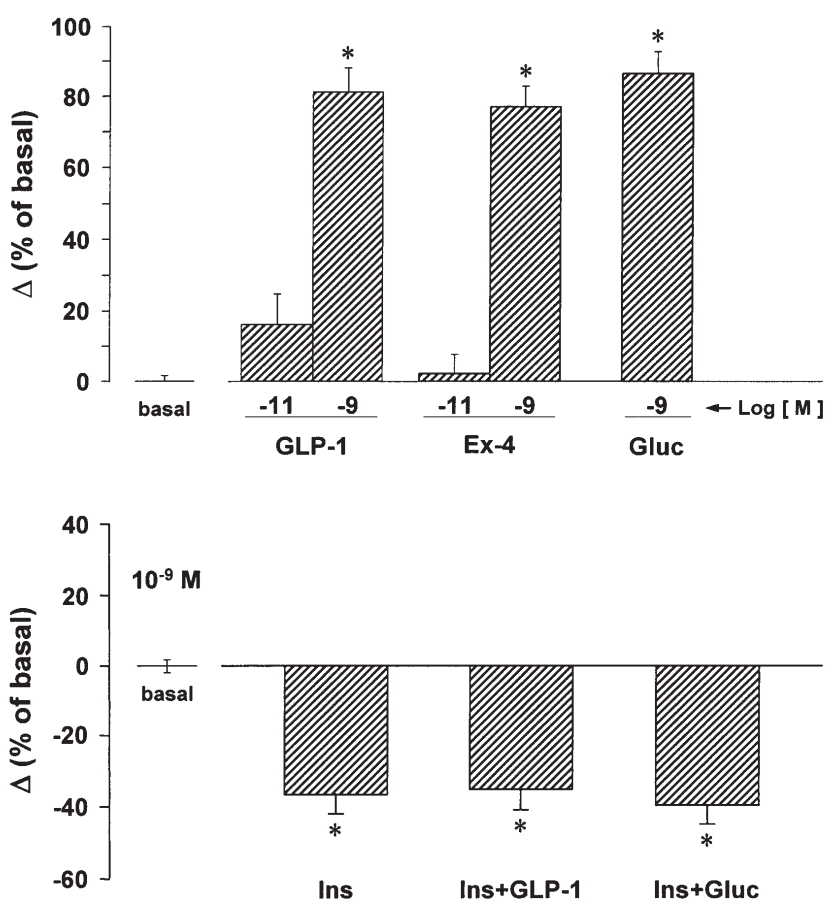

Figure 2. Effect of GLP-1, Ex-4 and glucagon (Gluc) (upper panel) and $10^{-9} \mathrm{M}$ insulin (Ins), alone and in combination with $10^{-9} \mathrm{M}$ GLP-1 or glucagon (lower panel), upon the glycerol released by isolated adipocytes from 6-14 morbidly obese patients. Data (mean \pm SEM) are expressed in percent increment, relative to paired basal value. ${ }^{*} \mathrm{p}<0.001$.

Lipolysis. The basal rate of lipolysis in the adipocytes of obese patients averaged $21.1 \pm 2.3 \mathrm{nmol}$ of glycerol per $10^{5}$ cells ( $\mathrm{n}=14$ subjects). Relative to the paired basal value, the rate of lipolysis was increased $(\mathrm{p}<0.001)$ to a comparable extent by $10^{-9}$ GLP-1, Ex-4 and glucagon (Fig. 2). Insulin $\left(10^{-9} \mathrm{M}\right)$ inhibited basal lipolysis $(\mathrm{p}<0.001)$ and abolished the lipolytic effect of $10^{-9} \mathrm{M}$ GLP-1 or glucagon.

The basal lipolysis in obese patients was higher $(\mathrm{p}<0.05)$

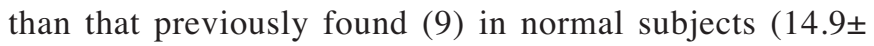
$0.9 \mathrm{nmol} / 10^{5}$ cells, $\mathrm{n}=11$ ). Relative to the paired basal value, the rate of glycerol release recorded in the presence of either GLP-1 or glucagon $\left(10^{-9} \mathrm{M}\right.$ each) was also higher $(\mathrm{p}<0.05)$ in the obese patients than in normal subjects, in which the results averaged, relative to basal values, $143 \pm 14 \%(n=7)$ in the presence of GLP-1 and $145 \pm 12 \%(n=13)$ in the presence of glucagon. In normal subjects, the previously reported rate of lipolysis averaged $84 \pm 5 \%(n=15)$ in the sole presence of insulin $\left(10^{-9} \mathrm{M}\right)$, and $71 \pm 10 \%(\mathrm{n}=12)$ and $74 \pm 10 \%(\mathrm{n}=10)$ in the presence of insulin $\left(10^{-9} \mathrm{M}\right)$ combined, respectively, with either GLP-1 $\left(10^{-9} \mathrm{M}\right)$ or glucagon $\left(10^{-9} \mathrm{M}\right)$. None of these three percentages found in normal subjects was significantly different $(\mathrm{p}>0.1)$ from the corresponding mean value recorded in cells from obese patients (Fig. 2).

Lipogenesis. In the adipocytes of obese patients, the basal rate of lipogenesis $\left(4.9 \pm 0.3 \mathrm{nmol} / 10^{5}\right.$ cells, $\mathrm{n}=6$ subjects $)$ was higher $(\mathrm{p}<0.001)$ than that previously found (9) in cells from normal subjects $\left(2.9 \pm 0.2 \mathrm{nmol} / 10^{5}\right.$ cells, $\left.\mathrm{n}=7\right)$.

GLP-1 $\left(10^{-13}-10^{-9} \mathrm{M}\right)$, Ex-4 and Ex-9 (both $10^{-12}-10^{-9} \mathrm{M}$ ) tended to increase lipogenesis; this effect though only achieved statistical significance on a few occasions, i.e. in the presence 
Table I. Lipogenesis in adipocytes from obese patients. ${ }^{a}$

\begin{tabular}{lcccccc}
\hline & Nil & $10^{-13} \mathrm{M}$ & $10^{-12} \mathrm{M}$ & $10^{-11} \mathrm{M}$ & $10^{-10} \mathrm{M}$ & $10^{-9} \mathrm{M}$ \\
\hline Basal & $100.0 \pm 4.0$ & & & & & \\
GLP-1 & & $113.7 \pm 6.7$ & $111.4 \pm 7.7$ & $111.1 \pm 7.7$ & $113.4 \pm 8.8$ & $104.6 \pm 3.9$ \\
Ex-4 & & - & $123.8 \pm 7.0^{\mathrm{b}}$ & - & $110.3 \pm 7.1$ & $102.8 \pm 5.7$ \\
Ex-9 & & - & $104.7 \pm 4.6$ & - & $113.1 \pm 8.1$ & $121.8 \pm 7.1^{\mathrm{b}}$ \\
Insulin & & - & - & - & - & $151.2 \pm 6.6^{\mathrm{b}}$ \\
\hline
\end{tabular}

${ }^{\mathrm{a}}$ Data (mean $\left.\pm \mathrm{SEM}\right)$ are expressed in percent relative to paired basal value $\left(4.9 \pm 0.3 \mathrm{nmol} / 10^{5}\right.$ cells, $\mathrm{n}=6$ subjects). ${ }^{\mathrm{b}} \mathrm{p}<0.03 \mathrm{vs}$ basal value.

of either $10^{-12}$ M Ex-4 ( $\left.<<0.02\right)$ or $10^{-9}$ M Ex-9 $(\mathrm{p}<0.03)$. Nevertheless, when all readings obtained with GLP-1, or with its two related peptides, were pooled, a significant increase in lipogenesis was reached, with mean values of $110.8 \pm 3.0 \%$ $(n=30 ; p<0.01)$ in the presence of GLP-1, 112.3 $\pm 4.2 \%(n=18$; $\mathrm{p}<0.01)$ in the presence of Ex-4 and $113.2 \pm 4.0 \% \quad(n=18$; $\mathrm{p}<0.01)$ in the presence of Ex-9. The latter three percentages were not significantly different from one another $(p>0.6)$ and much lower $(\mathrm{p}<0.001)$ than that induced by $10^{-9} \mathrm{M}$ insulin (151.2 $\pm 6.6 \% ; n=6 ; p<0.001$ versus unity).

These results on lipogenesis are qualitatively comparable to those previously recorded in adipocytes from normal subjects (9) in which, and over the same range of concentrations $\left(10^{-13}-10^{-9} \mathrm{M}\right)$, the mean value recorded in the presence of GLP-1 $(123.4 \pm 2.5 \% ; n=35)$, and expressed relative to paired basal value, was somewhat higher $(\mathrm{p}<0.005)$ than in obese patients (see above). On the contrary, the lipogenetic response to insulin $\left(10^{-9} \mathrm{M}\right)$ was higher $(\mathrm{p}<0.05)$ in obese patients than in normal subjects $(126 \pm 8 \% ; n=7)$.

As documented in Table I, the trend was towards a decrease in the lipogenetic action of both GLP-1 and Ex-4 as their concentration increased, with a mirror image in the case of Ex-9. The $10^{-9} \mathrm{M} / 10^{-12} \mathrm{M}$ ratio in lipogenesis was significantly lower $(\mathrm{p}<0.005)$ in the case of GLP-1 and Ex-4 $(88.4 \pm 4.5 \%$; d.f. $=20)$ than in the case of Ex-9 $(116.3 \pm 8.5 \%$; d.f.=10).

\section{Discussion}

In the present study, both GLUT4 protein and mRNA in adipocytes from obese patients showed a trend toward lower values as compared to normal subjects, although the difference did not reach statistical significance. In other published studies, where statistically significant lower values were reported in overweight subjects (32-34), the patients suffered obesity associated with insulin resistance or type 2 diabetes. Our data also reveal that, in adipocytes from obese subjects, insulin but not GLP-1 $\left(10^{-12}-10^{-9} \mathrm{M}\right)$ stimulated 2-deoxy-D-glucose uptake, whilst both Ex-4 and Ex-9, at high concentrations $\left(10^{-10}-10^{-9} \mathrm{M}\right)$, exerted inhibitory action. To our knowledge, the effect of GLP-1, Ex-4 and Ex-9 on 2-deoxy-D-glucose uptake in adipocytes from normal subjects has not yet been investigated. The present results suggest that exendins and GLP-1 use distinct signaling pathways in human adipocytes. In fact, it has been previously observed that, in human myocytes, both exendins, like GLP-1, stimulate glucose metabolism; however, while the three peptides and insulin provoke the immediate hydrolysis of glycosylphosphatidylinositol, suggesting the generation of an inositolphosphoglycan considered as a second messenger in the insulin action, only Ex-9 is able to induce an immediate increase in the cellular cAMP content (12). Also, it has been observed that, in fat cells from either normal or streptozotocin-induced type 2 diabetic rats, GLP-1 and both exendins significantly stimulate D-glucose transport in a dose-related manner, up to $10^{-9} \mathrm{M}(6)$.

The basal rate of lipolysis, expressed per cell, was higher in adipocytes from obese patients than in those from normal subjects (9), and such was also the case for the enhancing effect of GLP-1 and glucagon. The inhibitory action of insulin on either basal or glucagon- and GLP-1-stimulated lipolysis was comparable, however, in normal and obese subjects. The increased basal and hormone-stimulated rates of lipolysis in the adipocytes of obese subjects could be linked, in part at least, to their higher content in triglycerides. Incidentally, no lipolytic effect of either GLP-1 or glucagon was observed in an in vivo study conducted in normal subjects (35).

The basal rate of lipogenesis was also higher in the adipocytes of obese versus normal subjects. In this case, however, the response to GLP-1 was lower in the obese patients, with a mirror image in the case of insulin. Moreover, in the obese group, and at variance with the situation found in normal subjects (9), the concentration-response relationship for the lipogenic effect of GLP-1 failed to display a progressive rise at increasing concentrations of the peptide. A comparable situation was found with Ex-4 in cells from obese patients. But the results obtained with GLP-1 and Ex-4 differed from those observed in the case of Ex-9, which exerts increasing lipogenic action as the concentration of the peptide raises. In this regard, possible species differences should be considered; it has been documented that, in rat adipocytes, GLP-1 and both exendins are indeed lipogenic (6).

In conclusion, the present results document both analogies and dissimilarities between the effects of GLP-1 and its structurally related peptides, Ex-4 and Ex-9, as well as insulin, upon two fundamental biochemical variables of the adipocyte metabolism, lipolysis and lipogenesis, when comparing the behavior of cells obtained from obese patients versus normal subjects. It may be premature to speculate on the relevance of the present findings; yet, they should not be ignored, considering the possible use of GLP-1 and its related peptides as tools in the treatment of glucose intolerance and type 2 diabetes mellitus, which are common in obese patients. Likewise, the reduced lipogenic action and increased lipolytic 
effect of GLP-1 in fat cells from obese subjects should be considered in the perspective of its therapeutic use as a proven anorectic agent in obesity (36).

\section{Acknowledgements}

We are grateful to E. Martín-Crespo for technical assistance. This study was supported by grants from the Ministerio de Educación y Cultura (BFI 2003-07399) and the Institute of Health Carlos III (G03/212 and C03/08), Spain. V.S., M.V.T., N.G., A.A. and L.A. are research fellows from the Fundación Conchita Rábago de Jiménez Díaz.

\section{References}

1. Egan JM, Meneilly GS, Habener JF and Elahi D: Glucagonlike peptide- 1 augments insulin-mediated glucose uptake in the obese state. J Clin Endocrinol Metab 87: 3768-3773, 2002.

2. Valverde I, Villanueva-Peñacarrillo MV and Malaisse WJ: Pancreatic and extrapancreatic effects of GLP-1. Diabetes Metab 28: 3S85-3S $89,2002$.

3. Creutzfeldt W: The entero-insular axis in type 2 diabetes. Incretins as therapeutic agents. Exp Clin Endocrinol Diabetes 109: S288-S303, 2001

4. Villanueva-Peñacarrillo ML, Puente J, Redondo A, Clemente F and Valverde I: Effect of GLP-1 treatment on GLUT2 and GLUT4 expression in NIDDM and IDDM rats. Endocrine 15: 241-248, 2001.

5. Acitores A, González N, Sancho V, Arnés L, Valverde I, Malaisse WJ and Villanueva-Peñacarrillo ML: Participation of protein kinases in the stimulant action of GLP-1 upon 2-deoxyD-glucose uptake by normal rat skeletal muscle. Horm Metab Res: 37: 275-280, 2005.

6. Sancho V, Trigo MV, González N, Valverde I, Malaisse WJ and Villanueva-Peñacarrillo ML: Effects of GLP-1 and exendins on kinase activity, 2-deoxy-D-glucose transport, lipolysis and lipogenesis in adipocytes from normal and streptozotocininduced type 2 diabetic rats. J Mol Endocrinol 35: 27-38, 2005.

7. Ruiz-Grande C, Alarcón C, Mérida E and Valverde I: Lipolytic action of glucagon-like peptides in isolated rat adipocytes. Peptides 13: 13-16, 1992.

8. Perea A, Viñambres C, Clemente F, Villanueva-Peñacarrillo ML and Valverde I: GLP-1(7-36)amide effects on glucose transport and metabolism in rat adipose tissue. Horm Metab Res 9: 417-421, 1997.

9. Villanueva-Peñacarrillo ML, Márquez L, González N, DíazMiguel M and Valverde I: Effect of GLP-1 on lipid metabolism in human adipocytes. Horm Metab Res 33: 73-77, 2001.

10. Valverde I, Morales M, Clemente F, López-Delgado MI, Delgado E, Perea A and Villanueva-Peñacarrillo ML: Glucagonlike peptide-1: a potent glycogenic hormone. FEBS Lett 349: 313-316, 1994.

11. Villanueva-Peñacarrillo ML, Alcántara A, Clemente F, Delgado E and Valverde I: Potent glycogenic effect of GLP-1 (7-36)amide in rat skeletal muscle. Diabetologia 37: 1163-1166, 1994.

12. Luque MA, González N, Márquez L, Acitores A, Redondo A, Morales M, Valverde I and Villanueva-Peñacarrillo ML: GLP-1 and glucose metabolism in human myocytes. J Endocrinol 173: 465-473, 2002.

13. Valverde I, Mérida E, Delgado E, Trapote MA and VillanuevaPeñacarrillo ML: Presence and characterization of glucagon-like peptide-1(7-36)amide receptors in solubilized membranes of rat adipose tissue. Endocrinology 132: 75-79, 1993.

14. Villanueva-Peñacarrillo ML, Delgado E, Trapote MA, Alcántara AI, Clemente F, Luque MA, Perea A and Valverde I: Glucagon-like peptide-1 binding to rat hepatic membranes. J Endocrinol 146: 183-189, 1995.

15. Delgado E, Luque MA, Alcántara A, Trapote MA, Clemente F, Galera C, Valverde I and Villanueva-Peñacarrillo ML: Glucagonlike peptide-1 binding to rat skeletal muscle. Peptides 16: 225-229, 1995.

16. Yang H, Egan JM, Wang Y, Moyes D, Roth J, Montrose MH and Montrose-Rafizadeh C: GLP-1 action in L6 myotubes is via a receptor different from the pancreatic GLP-1 receptor. Am J Physiol 275: C675-C683, 1998.
17. Thorens B: Expression cloning of the pancreatic beta cell receptor for the gluco-incretin hormone glucagon-like peptide-1. Proc Nat Acad Sci USA 89: 8641-8645, 1992.

18. Redondo A, Trigo MV, Acitores A, Valverde I and VillanuevaPeñacarrillo ML: Cell signalling of the GLP-1 action in rat liver. Mol Cell Endocrinol 204: 43-50, 2003.

19. Acitores A, González N, Sancho V, Valverde I and VillanuevaPeñacarrillo ML: Cell signalling of glucagon-like peptide-1 action in rat skeletal muscle. J Endocrinol 180: 389-398, 2004.

20. Ranganath LR, Beety JM, Morgan LM, Wright JW, Howland R and Marks V: Attenuated GLP-1 secretion in obesity: cause or consequence? Gut 38: 916-919, 1996.

21. Lugari R, Dei Cas A, Ugolotti D, Barilli AL, Camellini C, Ganzerla GC, Luciani A, Salerni B, Mittenperger F, Nodari S, Gnudi A and Zandomeneghi R: Glucagon-like peptide 1 (GLP-1) secretion and plasma dipeptidyl peptidase IV (DPP-IV) activity in morbidly obese patients undergoing biliopancreatic diversion. Horm Metab Res 36: 111-115, 2004.

22. Valverde I, Puente J, Martín-Duce A, Molina L, Lozano O, Sancho V, Malaisse WJ and Villanueva-Peñacarrillo ML: Changes in glucagon-like peptide-1 (GLP-1) secretion after biliopancreatic diversion or vertical banded gastroplasty in obese subjects. Obes Surg 15: 387-397, 2005.

23. Cancelas J, Villanueva-Peñacarrillo ML, Valverde I and Malaisse WJ: Synergistic insulinotropic effects of succinic acid dimethyl ester and exendin-4 in anaesthetized rats. Int J Mol Med 8: 269-271, 2001.

24. Alcántara AI, Morales M, Delgado E, López-Delgado MI, Clemente F, Luque MA, Malaisse WJ, Valverde I and VillanuevaPeñacarrillo ML: Exendin-4 agonist and exendin(9-39)amide antagonist of the GLP-1(7-36)amide effects in liver and muscle. Arch Biochem Biophys 341: 1-7, 1997.

25. Nielsen LL, Young AA and Parkes DG: Pharmacology of exenatide (synthetic exedin-4): a potential therapeutic for improved glycemic control of type 2 diabetes. Regul Pept 117: $77-88,2004$.

26. Cancelas J, Villanueva-Peñacarrillo ML, Valverde I and Malaisse WJ: Suppression by exendin(9-39)amide of glucagonlike peptide 1 insulinotropic action in rats infused with the dimethyl ester of succinic acid. Endocrine 15: 283-285, 2001.

27. González N, Acitores A, Sancho V, Valverde I and VillanuevaPeñacarrillo ML: Effect of GLP-1 on glucose transport and its cell signaling in human myocytes. Regul Pept 126: 203-211, 2005.

28. Montrose-Rafizadeh C, Yang H, Wang Y, Roth J, Montrose MH and Adams LG: Novel signal transduction and peptide specificity of glucagon-like peptide receptor in 3T3-L1 adipocytes. J Cell Physiol 172: 275-283, 1997.

29. Rodbell M: Metabolism of isolated fat cells. I. Effects of hormones on glucose metabolism and lipolysis. J Biol Chem 239: 375-380, 1964

30. Wieland O: Glycerol. In: Methods in Enzymatic Analysis. Bergmeyer HU (ed). Academic Press, New York, pp211-214, 1963.

31. Perea A, Clemente F, Martinell J, Villanueva-Peñacarrillo ML and Valverde I: Physiological effect of glucagon in human isolated adipocytes. Horm Metab Res 27: 372-375, 1995.

32. Garvey WT, Malanu L, Huecksteadt TP, Bimbaum MJ, Molina JN and Ciaraldi TP: Pretranslational suppression of a glucose transporter protein causes insulin resistance in adipocytes from patients with non-insulin-dependent diabetes mellitus and obesity. J Clin Invest 87: 1072-1081, 1991.

33. Sinha MK, Rainieri-Maldonado C, Buchanan C, Pories WJ, Carter-Su C, Pilch PF and Caro JF: Adipose tissue glucose transporters in NIDDM. Decreased levels of muscle/fat isoform. Diabetes 40: 472-477, 1991.

34. Giacchetti G, Faloia E, Taccaliti A, Morosini PP, Arnaldi G, Soletti F, Mantero F, Accili D and De Pirro R: Decreased expression of insulin-sensitive glucose transporter mRNA (GLUT-4) in adipose tissue of non-insulin-dependent diabetic and obese patients: evaluation by a simplified quantitative PCR assay. J Endocrinol Invest 17: 709-715, 1994.

35. Bertin E, Arner P, Bolinder J and Hagstrom-Toft E: Action of glucagon and glucagon-like peptide-1-(7-36) amide on lipolysis in human subcutaneous adipose tissue and skeletal muscle in vivo. J Clin Endocrinol Metab 86: 1229-1234, 2001.

36. Gutzwiller JP, Degen L, Heuss L and Beglinger C: Glucagonlike peptide 1 (GLP-1) and eating. Physiol Behav 82: 17-19, 2004. 